УAK 339.972

O. Volynets,

State educational and scientific institution "Academy of Financial Management" of Kyiv

ORCID ID: 0000-0002-1188-3764

D. Bondarenko,

State educational and scientific institution "Academy of Financial Management" of Kyiv

ORCID ID: 0000-0002-2802-2397

V. Oleksiuk,

Student of the International Relations School, Taras Shevchenko National University of Kyiv

ORCID ID: 0000-0002-1351-2617

DOI: $10.32702 / 2306-6792.2019 .12 .39$

\title{
THEORETICAL AND METHODOLOGICAL AND METHODICAL FOUNDATIONS OF INNOVATIVE DEVELOPMENT OF INTERNATIONAL AGRIBUSINESS
}

\author{
О. Я. Волинець, \\ аспірант АННУ "Академія фінансового управління" \\ ORCID ID: 0000-0002-1188-3764 \\ А. В. Бондаренко, \\ аспірант АННУ "Академія фінансового управління" \\ ORCID ID: 0000-0002-2802-2397 \\ B. I. Олексюк, \\ студент Інституту міжнародних відносин Київського національного університету імені Тараса Шевченка \\ ORCID ID: 0000-0002-1351-2617
}

\section{ТЕОРЕТИКО-МЕТОАОАОГІЧНІ Й МЕТОАИЧНІ ПІАОЙМИ ІННОВАЦІЙНОГО РОЗВИТКУ МІЖНАРОАНОГО АГРОБІЗНЕСУ}

The conducted scientific research provides new solutions to the current scientific issue in the theoretical and applied methodological and methodical study of the tendency of innovative developments in the ontogeny of international agribusiness in the conditions of globalization, financing and world-orientation of agroeconomic systems to comprehensive sustainable development, including through the inclusion means, in particular, we proposed and/or further developed the following items:

Classification of innovations groups in the international agribusiness into two types: the first type is innovations embodied in means of production or products (agricultural machinery, fertilizers and seeds); the second type is "elusive" or "scattered" innovations (integrated pest control schemes);

the key elements of the innovation policy of international agribusiness are growing cooperation, the introduction of high-tech solutions in the production process and technologically new products, the placement of research centers not only in the mother country, but also in other countries to adapt commercial developments to local legislation and climatic conditions of agricultural production and processing of agricultural raw materials;

the "Big six" companies (Bayer-Monsanto, Dow-DuPont and ChemChina-Syngenta) that shape the effect of innovative inertia in international agribusiness and the transformation of the world food market were identified;

the need for innovative development of the agricultural sector of the Ukraine's economy which will provide a solution to a number of historical crisis-related problems (including the optimization of the sectoral structure of the industry, the stabilization of the agricultural food chains to create high added value, the diversification of the export structure, the reduction of dependence on imports of food with high added value), as well as the establishment of foundations for the transition from the export-raw material to the innovative model of the agricultural economy through the use of innovative technologies, the creation of high-tech agricultural production, and the stimulation of their innovation activity.

Проведене наукове дослідження дозволило запропонувати нове вирішення актуального наукового завАання щодо теоретико-прикладного й методолого-методичного досліАження тенденційності інноваційних поступів в онтогенезі міжнародного агробізнесу в умовах глобалізації, фінансовізації та світ-орієнтації агроекономічних систем на все- 
охоплюючий сталий розвиток у тому числі й засобами інклюзії, зокрема запропоновано та/або дістало подальшого розвитку:

класифікація групування інновацій в міжнародному агробізнесі за двома типами: перший, інновації, втілені у засобах виробництва або продукції (сільгосптехніка, добрива і насіння); другий - "невловимі" або "розсіяні" інновації (інтегровані схеми контролю за шкідниками рослин);

ключові елементи інноваційної політики агроорієнтованого міжнародного бізнесу - зростаюча кооперація, впровадження високотехнологічних рішень у виробничих процес і технологічно нового продовольства, розміщення науково-дослідницьких центрів не тільки в материнській країні, але і в інших країнах Аля аАаптації комерційних розробок до місцевого законодавства й природно-кліматичних умов ведення сільгоспвиробництва й переробки сільгоспсировини;

визначені компанії "Великої шістки" (Bayer-Monsanto, Dow-DuPont i ChemChina-Syngenta), що формують ефект інноваційного інерціювання в міжнародному агробізнесі й трансформації світового продовольчого ринку;

необхідність інноваційного розвитку аграрного сектора економіки України, що дозволить забезпечити вирішення відразу низки історично сформованих кризогенних проблем (зокрема щодо оптимізації галузевої структури сектору, стабілізації агропродовольчих ланцюгів створення високої доданої вартості, диверсифікації структури експорту, зниження залежність від імпорту продовольства з високою доданою вартістю), а також сформувати підойми Аля переходу віА експортно-сировинної до інноваційної моделі аграрної економіки за рахунок використання інноваційних технологій, створення високотехнологічних агровиробництв, стимулювання їх інноваційної активності.

Key words: GMO, innovations, international agribusiness, new technologies, STP (scientifictechnological progress), food supply.

Ключові слова: ГМО, інновачї̈, міжнародний агробізнес, нові технологї, НТП, продоволь$c m B o$.

\section{STATEMENT OF THE PROBLEM IN GENERAL AND ITS CONNECTION WITH IMPORTANT SCIENTIFIC OR PRACTICAL TASKS}

The concept and the term "agribusiness" were first introduced into scientific usage after the Second World War. In 1957, the fundamental work of the representatives of Harvard Business School, J. Davis and Ray Goldberg, "The Concept of Agribusiness. Division of Research", in which the economy is considered as an independent branch of research was published. The authors used the term "agribusiness" to describe the interrelated functions of agriculture and industrial and financial business, which meant the total number of operations involved in the production and distribution of agricultural products, the process of production at the farm, storage, processing and distribution of agricultural products and food. Subsequently, in the theory of the functioning of the world economy at the corporate level, the conceptual foundations of agribusiness were developed in two parallel levels of tendency measurement: the first was called "agribusiness economy" which means the study of vertical and horizontal coordination between the participants within the framework of the agro-food chain at the micro and macro level; the second was "agribusiness management" which means the study of decision-making within the framework of alternative agro-food sector management structures.

Numerous global concepts were devoted to the determination of the tendency of the development of international agribusiness through changes in the effective operational indicators, where the key determinant was the technological institutional changes expressed through agroinnovations - new methods, options or means used to perform the tasks by agroeconomic system, in particular to ensure the achievement of Goal \# 2 "Overcoming hunger, achieving food security, improving nutrition and promoting sustainable development of agriculture" contained in the United Nations Global Sustainable Development Goals to 2030. At present, the radical transformation of the agrofood system is global in nature, and the agroindustrialization process is a complex socioeconomic phenomenon, which is considered by most researchers as a period of individual and collective stress on the background of related changes and economic "disorder". 
THE ANALYSIS OF RECENT RESEARCHES AND PUBLICATIONS, WHICH INITIATED THE SOLUTION OF THIS PROBLEM AND ON WHICH THE AUTHOR RELIES, DETERMINED THE PREVIOUSLY UNSOLVED PARTS OF THE GENERAL PROBLEM TO WHICH

\section{THIS ARTICLE IS DEVOTED}

The formation of the theoretical and methodological foundations of the research of technology influence on the global economy in general and on the operation and development of multi-sectoral entrepreneurial institutions in particular, was carried out by such renowned scholar as Daniel Bell, Manuel Castells, Charles Cobb, Edward Denison, Robert Fogel, Mykola Kondratiev, Simon Kuznets, Robert Lucas, Douglas Pearce, Paul Romer, Joseph Schumpeter, Robert Solow, George Thwaites, et al.

The behavioral model of the national innovation system, its impact on the transformation of business entities, the formation of new competitive advantages in the international goods market through technological innovations were studied by the following scholars: I. Amosha. Y. Bazhal, O. Bilorus, I. Burakovsky, Z. Varnaly, V. Verhun, S. Hasanov, V. Heiets, A. Gritsenko, A. Danylenko, I.Zhalilo, O.Zhylinska, V.Zymovets, P. Leonenko, E. Libanova, V. Novytsky, Y. Pakhomov, T. Rozhkova, V. Rokocha, O. Tereshchenko, L. Fedulova, V. Haustov, et al.

The phenomenon of "penetration" by innovations of international, regional, national and local agricultural systems has been studied for a long time only within the framework of highly specialized agricultural researches. However, in the late XX - early XXI century, the phenomenon study started within the framework of economics. Thus, the features of functioning and development of innovations in the international agricultural business through the prism of nano-, bio-, information-communication and convergent technologies, their inertia to the agricultural sector of the national economy were analyzed in the works of such Ukrainian (V. Andriychuk, V. Vlasov, P. Haidutsky, B. Duhnytsky, V. Zhuk, Sh. Ibatullin, H. Kaletnik, M. Kropyvko, Y. Lupenko, V. Mesel-Veseliak, I. Novak, S. Petrukha, M. Puhachev, P. Sabluk, V. Trehobchuk, O. Khodakivska, O. Shubaly, O. Shpykuliak, O. Shubravska) and foreign (Julio Berdegue, Katarzyna Bijak, Gianluca Brunori, J.-Jacques Dethier, Paul Diederen, German Escobar, Alain Janvry, Knickel Karlheinz, John Knight, Hans Meijl, Sharada Weir, Tassew Woldehanna, Arjan Wolters) scientists.

That is, only individual theoretical, methodological and methodical aspects of agribusiness development, the impact of agro-oriented scientific and technological progress on the situation in the international food market were considered in the research and popular science literature. However, there were no attempts to carry out a cross-cutting evaluation of the "innovation - international agribusiness - world food market" triad, thereby actualizing the conduct of this kind of research.

\section{FORMULATING THE ARTICLE GOALS (STATEMENT OF THE PROBLEM)}

Identification of transformation and modernization mechanisms of the economic paradigm of the international agribusiness functioning under the influence of innovative technologies on the basis of modern mainstream research of the innovative context of the world food market development.

\section{PRESENTATION OF THE MAIN RESEARCH MATERIAL WITH FULL JUSTIFICATION OF THE SCIENTIFIC RESULTS OBTAINED}

A prerequisite for increasing the role of innovative aspects of international agribusiness development are effective mechanisms for managing the development and implementation of innovations and innovative technologies. At the same time, the theoretical and methodological basis for the provision of innovative technologies in agribusiness should be formed taking into account both the past and the latest paradigm of innovation activity.

In the world literature, economic innovation is mainly interpreted as the transformation of potential scientific and technological progress (STP) into real one which is embodied in new products and technologies $[3 ; 5 ; 7 ; 12]$. On the basis of processing and systematization of the scientists' opinions presented in the foreign economic literature on the essence of innovation, we will formulate our own definition of this concept. These are certain material objects or processes that provide new, previously unknown characteristics and properties, while these objects or processes are ahead of their predecessors in their functional characteristics.

The continuous development of STP, the formation of a new technological structure and the transition from industrial to a post-industrial society based on innovative knowledge occur through the transformation of all social life spheres, which are reflected in the transfer of the economic development gravity center to scienceintensive and high-tech spheres. 
Table 1. Share of technological orders in some countries of the world

\begin{tabular}{|l|c|c|c|c|}
\hline \multirow{2}{*}{ Country } & \multicolumn{4}{|c|}{ Technological order } \\
\cline { 2 - 5 } & First & Fourth & Fifth & Sixth \\
\hline Ukraine & M & H & L & \\
\hline USA & & L & H & M \\
\hline China & & L & H & M \\
\hline $\begin{array}{l}\text { Russian } \\
\text { Federation }\end{array}$ & & H & M & L \\
\hline
\end{tabular}

Legend: L - low share (of total GDP), $\mathrm{M}$ - medium share; $\mathrm{H}$ high share. $16]$.

Source: made by the author according to data $[1 ; 8 ; 10 ; 12-13$;

The "post-industrial society" term was introduced into scientific usage in 1959 by the sociologist D. Bell during his speech at the sociological seminar in Salzburg (Austria) to describe "the society in which science and knowledge are the main productive forces. Technologies play a key role, and the industrial sector is losing its leading role due to increasing tecnification" [11].

Depending on the production mode, three types of society are distinguished: pre-industrial, industrial and post-industrial. There are three criteria in the basis of fundamental differences of each of them: basic production resource, type of production activity, basic technologies.

The production of raw materials and primary conditions for agricultural production where the leading place in the economy is occupied by the mining industry with the use of labor-intensive technologies is characteristic for the pre-industrial society. The industrial society provides for the use of energy as the main production resource, while the main type of activity is the manufacture or production of goods, and the basic technology is capital-intensive technology. The post-industrial society is characterized by the use of scienceintensive technologies, which causes the demand for information as the main production resource, and the leading industry in the economy is the service sector on which the industrial efficiency depends.

At the same time, the transition from one type of society to another is the result of technological revolutions (agricultural, industrial, scientific and technical) and changes in the established production process, which begin with the introduction of new basic technologies. It should be noted that the scientific and technical revolution (STR) has determined the transition to the computer, nuclear, space age which mainly determines the formation of a post-industrial society at the present stage.

The basic technologies have certain degrees which are called "technological orders" in indust- rial and post-industrial society and occur in accordance with the concept of long waves by $\mathrm{N}$. Kondratiev which includes six technological orders. Four modes are a part of the industrial stage, the other two are based on nano- and information and communication technologies and belong to the post-industrial orders, which is characterized by the transition from capital-intensive to scienceintensive technologies. Consequently, the capital capacity increases, since the capital is replaced by labor $[6 ; 14]$.

Between 1960 and 1970, American scientist J. Galbraith also contributed to the formation of the "industrial society" theory. A special role was assigned to large corporations that operate in three markets: raw materials and equipment market, capital markets and labor market [17$18]$.

Modern scientists have expanded the list of basic technologies of technological orders: the core of the fifth technological order includes information and communication technologies; the core of the sixth technological order includes nanotechnology. Japanese economist M. Xirooki identified the basic technologies for the sixth Kondratiev's cycle: multimedia, nanotechnology, biotechnology, genetic engineering and regeneration of human organs, superconductors, quantum computers, etc [15; 17].

The table 1 provides a comparative analysis of the development of technological orders in different countries.

The study of economic problems of science and impact of technology on the economy of the countries in the second half of the twentieth century devoted a considerable amount of works of foreign and domestic scholars whose research is carried out within the framework of technological theories. Four consecutive periods can be identified in their development:

1. In the period from 1910 to 1930 , it was assumed that new technologies that are introduced into production, cause revolutionary changes in the commercial and industrial sectors and lead to the establishment of a new optimized production model. Firstly, M. Kondratiev described the idea of the relationship between the development of STP and the cyclical nature of innovations in the theory of large cycles within a framework of which he noted a special role of the STP and considered its influence on the economic development dynamics.

Later, J. Schumpeter continued studying the contribution of STP to economic growth in his work "Economic Cycles" in which he called the big economic cycles as Kondratiev's cycles. In general, 
economists of this era (M. Castells, M. Kondratiev, S. Koval, J. Schumpeter, Ch. Cobb, P. Douglas) tried to answer the question of the extent to which the proportions of factors (labor, land, and capital) affect economic growth.

2. In the period between 1940 and 1970, the economists focused on the search for the optimal ratio of production factors and the impact of population growth, savings and technology on the economic growth and production function (R. Solow, E. Denison, J. Kendrick). R. Solow's school interpreted STP as an exogenous factor, a remainder within the production function, a value of which can be estimated by the value of the labor and capital contribution to economic growth. The peculiarities of this school are clearly expressed in the "Solow's paradox". In the late 1980s, he stated that the computer is visible everywhere, but not in labor productivity statistics.

Economists H. Mensch and K. Freeman discovered that the STP has an endogenous nature. The connection of its dynamics with large cycles or long waves of economic development was also revealed. Representatives of this school proved that the basic innovations that initiate the formation of new STP areas are mainly observed in periods of descending waves. At the same time, the new STR potential is accumulated. This was, in particular, the period from the late 1970s to the middle of the 1990s ("Solow's paradox" duration). The ascending wave of economic development is formed on the basis of large-scale use of the potential accumulated in the previous descending wave. The last ascending wave began with the acceleration of labor productivity growth in the US since the middle of the 1990s. [2;19].

The STP was considered as an exogenous factor by neoclassicists. Their contribution is to quantitatively assess the impact of STP on economic growth. Within the concept of large cycles, or waves of economic development, the STP acts as an exogenous factor. The descending wave stimulates the search for new directions of the STP, and the ascending one is based on their large-scale use for economic development.

3 . Since the middle of the 1970 s, some innovative economic models started to explain technology as an endogenous factor, which led to the introduction of new variables - human capital (G. Lucas, P. Romain, G. Mankiv) and the information. Thus, knowledge has become the main resource, and training - the most important process of ensuring the sustainable dynamics of economic systems.

4. The end of the XX century was a period of postindustrial society formation. At the same time, there is an associated theoretical breakthrough against the background of the development and dissemination of the epochal and basic innovations within the framework of the new technological order, the process of catching-up development in developing countries, as well as studying technical and economic paradigm (D. Ademoglu, J. Dosi, K. Freeman, S. Glaziev, C. Griliches, V. Klinov, R. Nelson, S. Winter, K. Peyvitt, K. Perez, P. Romer, A. Warsawsky).

The process of catching-up industrialization in developing countries follows different trajectories and is accompanied by the formation of national innovation networks, which provide for a system of different subjects (mega-institutes, national institutes, research centers, a mechanism for the formation of knowledge and innovation, the availability of indicative meters), the establishment of effective mechanisms of interaction between all institutions of the network and the creation of a favorable climate for producing knowledge.

Recently, we observe the tendency to increase the knowledge intensity of international agro-food systems, where an active introduction of high technologies takes place. The production process in the international agribusiness is being significantly transformed due to the tecnification and the growth of the industrial knowledge intensity, where the use of navigation systems, agrotechnics based on new materials, positioning systems, bio- and nanotechnology is spreading. However, such a transformation of individual industries (segments) of international agribusiness in the XXI century would be completely impossible without a gradual change in the technical and technological paradigm, the complication of the production process and the food itself, which lasted throughout the history of mankind, but gained the greatest development only in the XX century.

As incomes and capital accumulation increase, the share of agriculture in international agribusiness and its contribution to GDP declines. However, the events that took place in the second half of the twentieth century have changed the function of agriculture as a "servant" of industry, consolidating the importance of the sector as a component of economic and innovative growth and a fundamental factor for the sustainable development of countries with developing economies [10; 13; 22].

The agriculture gap in international agribusiness can have a negative impact on the world economy as a whole and on its innovation activity. Modern economists $[4 ; 12 ; 18 ; 21]$ distinguish four directions of its negative impact. First of all, the 
deficiency of food, which reduces productivity and means underinvestment in human capital. Secondly, food crises affect the political, economic stability and investment climate in the country. Thirdly, the discrepancy in the investment in the industrial and agricultural sectors generates multilevel capital productivity, worsening the efficiency of resource allocation in the economy. Finally, the high ability of international agribusiness to integrate breakthrough innovative technologies can accelerate the economic growth of the country.

The modern stage of the STP was called the industrial revolution 4.0. The new technologies bring radical changes to the entire economy, the speed of which is increased several times. The new type of production is based on Big Data, their analysis, complex automation of production, augmented reality technologies and the Internet. This innovative breakthrough began in the 1990s under the slogan of the "gene" revolution when Calgene Inc. US company launched the sale of genetically modified (GM) tomatoes. To date, the product of agrobiotechnology - genetically modified organisms (GMOs) - is an integral part of the world market of agricultural products and affects the resource sector of international agribusiness.

The most important prerequisite for the innovative development of agrobiotechnology was the ban on the use of biological weapons, which is reflected in the UN Convention which allowed to create a powerful layer of biological knowledge and the results of basic research in pharmaceuticals, medicine, industry, energy and agribusiness. A new round of discussions on the structure of the bio-economy in the EU and the USA, as well as sectors of the economy based on bioscientific and biotechnological innovations has provided additional urgency and incentives to the innovative development of international agribusiness through the biotechnology. The "biotechnology" is classically interpreted as a technological solution in the implementation of which the biological elements (extracted from organisms, for the manufacture or modification of the product, the improvement of plants or animals or the creation of microorganisms for specific purposes) can be applied [9]. In particular, biotechnology is called the science of the use of living processes in production, which is based on genetic engineering. When using a set of methods and approaches, natural sets of elements with modified and inherited characteristics are produced $[4 ; 13 ; 18]$.

Biotechnology is considered in a narrow and broad sense. In a broad sense, it is at the inter- section of biology and technology, scientific discipline and a field of practice that studies the ways and methods of changing the environment in accordance with its needs. In a narrow sense, biotechnology is a set of methods and techniques for obtaining useful products and phenomena using the biological agents [20;27].

During the genetic revolution, the structure of the costs of international agribusiness for food production has changed, in particular, the costs of research and development in agribusiness have increased; the costs of reproduction of fixed assets have decreased; labor costs have decreased; the costs of fertilizers have decreased but at the same time the cost of special types of protection of flora and fauna has increased. It should be noted that modern agrobiotechnology goes beyond genetic engineering and includes individual elements of genomics, which transforms the understanding of the functioning of genes, cells, organisms and ecosystems opening up new horizons for breeding with markers and genetic resources management. The use of agrobiotechnology in international agribusiness is still a subject of lively debate. The commercialization of GM crops is limited to individual varieties which are usually the forage crops with a small set of characteristics.

GMO is interpreted as artificial manipulations with the genome of living matter which is categorically unacceptable for the diametrically opposite concept of the international agribusiness development and by supporters of organic food. Thus, if the result of research and development in the GM sector is a product with unique properties due to external interference in the cell DNA, in organic farming this is a group of food with high quality characteristics [13; 23], produced without the plant protection chemicals (fertilizers, pesticides, GM seeds) in the regions with a relatively acceptable ecology. In general, such segregation of the world market by trademark continues to affect its condition.

It should be noted that, although in the studies of economists of the XX century, the agricultural sector is the leading branch of agribusiness and is considered as innovatively not active, at present the growth of research and development costs and the use of high-tech solutions in international agrofood systems have taken some of the agribusiness branches beyond the limits of low-tech sectors.

Technological and innovative development of international agribusiness is considered as a basic condition for catching-up development of the country. Therefore, the "green revolution" in India, East Africa and some other Asian countries, as well as the genetic revolution, proved that the 
use of knowledge-intensive technologies in international agribusiness can generally contribute to the growth of the volume of agricultural production, productivity and efficiency. In the XXI century, high technologies are the basic technologies for the agricultural industry of international agribusiness, namely: bio-, nano-, information and communication technologies and partially convergent technologies whose influence is reflected in important state-of-the-art factors of the present stage of the STP development.

That is, in the XXI century, a techno-economic paradigm of international agribusiness with the expressed innovations is developed, in particular through bio-, nano-, information and communication and partly convergent technologies which play a basic role in the stabilization of the creation of agro-food chains with high added value. The intensification of international agribusiness contributes to the solution of at least two key issues in ensuring its sustainable development. On the one hand, due to the development of high-tech agrosegments, preconditions for an accelerated increase in agricultural production are formed, and on the other hand, there is the promotion and/ or activation of the internal capacity to mitigate the severity of food security problem.

In this study, the authors understand the agrobusiness product under "high-tech food" in the production and/or in the production process of which bio-, nano-, information and communication and/or NBIC-technologies were used.

In recent years, especially after the agro-food crisis of 2008-2009, the most important factors for international agribusiness are the growth of the Earth's population in the conditions of inelastic supply of land resources, the rapid development of technologies to provide the ever-growing demand for agricultural products, yields increase, food losses reduction, and cost reduction of marginal food as well. Therefore, the catastrophic increase in the world's population, taking into account the geolocation limitations of the Earth, stimulates the search for technical and technological solutions to meet the growing demand for food in sufficient quantities.

Deepening of the STP processes and the emergence of new types of agricultural products at the end of the twentieth century led to the segregation of the agro-food market which is divided in modern literature $[4 ; 10 ; 24 ; 26]$ into three separate market segments: products of traditional agribusiness, GM products, and organic products. Such segregation leads to diversification and differentiation of agricultural product promotion channels, depending on the degree of artificial impact, as well as contributes to the emergence of multi-prices.

The developments of biotechnologists, which were firstly introduced into the market during the "gene" revolution, have firmly consolidated their positions, changing not only the structure of costs of international agribusiness and large agrochemical companies engaged in the resource sector, but also significantly transforming the entire global agro-food system, including the regulatory framework for the stabilization of the agro-food market. Over the last 20 years (19982018), agricultural biotechnologies and related GM crops [21], which were produced in 28 countries of the world [28] in 2018, became the most widespread [28].

The actual studies [ $8 ; 12-13 ; 16 ; 19]$ distinguish three key types of GM plants with three properties: the first - resistance to herbicides $(\mathrm{Ht})$; the second - insect resistance to Bacillus thuringiensis (Bt); the third - the combination of $\mathrm{Ht}$ and $\mathrm{Bt}$ symbols. At the present stage of the STP development, the first generation is the highyielding crops to improve efficiency and reduce production costs of international agribusiness. The second generation of GM crops is crops with high food value and predetermined consumer properties. The third generation includes crops that are pre-endowed with features identical to drugs, which, in particular, improve the biofuel processing, etc.

To date, the agricultural products authorized for sale are only genetically modified products (GMP) of the first generation, while others are at different stages of fundamental and applied research and development.

The benefits of agrobiotechnology include reducing the cost of food production. Despite the high cost of raw materials (seeds), GMP does not require or in some cases only partially requires minimal costs for chemical fertilizers.

The employment and productivity growth is increasing in the international agribusiness, which is more referred to developing countries [ $25 ; 28-$ 29]. The ecologization of agricultural production and the reduction of risks of crop failure are carried out through the rational management of pesticides. Thus, the GM crops which are resistant to pesticides, can improve soil conditions, reduce water pollution and the use of chemicals to protect agricultural plants.

In the period from 1998 to 2018, the economic effect of the use of GM crops in the world amounted to about 167.8 billion dollars; in developed countries -81.7 billion dollars; in developing countries -86.1 billion dollars $[9 ; 25$; 
28-29]. The five key producing countries account for the largest profit from the GMO commercialization, namely, the United States ( $\$ 73$ billion dollars), Argentina ( $\$ 21.1$ billion dollars), India ( $\$ 19.6$ billion dollars), China ( $\$ 18.6$ billion dollars) and Canada ( $\$ 7.3$ billion dollars). [16]. Regarding the profitability of the GMP use, it should be noted that this indicator for GM maize in the USA has increased and amounted to 20-36 dollars in 2018. (for comparison, in 2014, the use of GM corn allowed the American agribusiness to accumulate 1.6 billion dollars. [25; 28-29]).

According to a study by the University of North Carolina, the annual family budget for food through the use of GMOs amounted to 9,462 dollars, while it would be 12181 dollars without GMO. Thus, it can be argued that GMO-free products are on average $33 \%$ more expensive [8]. Also as a result of the study, it was determined that in the US households spend about $6.9 \%$ of the total budget on food, while in France - 13.9\%, and in Germany - 11.1\% [9; 21]. Nevertheless, despite some economic advantages, the debate about the safety of the GMP still continues, and this does not allow us to form clear targets for the long-term innovative development of international agribusiness. To this end, in February 2016, FAO held an International Symposium on "The Role of Agricultural Biotechnologies in Sustainability of Food Systems and Nutrition," which discussed the critical issues of biotechnology, its role in addressing food security issues, and ensuring sustainable innovative development of the international agribusiness [13]. As a result of the event, the experts involved concluded that there was no justification for the existing critical views on the production and consumption of GM food. However, there is no unanimous opinion among the scientific community, political figures, or society.

The World Health Organization does not classify GMPs as harmful food which affects the reproductive function of the population. According to experts of the organization, one of the strategic goals of further innovations in crop production on the basis of GMOs is the continuous improvement of plant protection products "currently, GM crops in the food market are mainly aimed at increasing their resistance to diseases caused by insects or viruses or increased resistance to herbicides" [13].

In July 2016, more than 100 Nobel laureates signed an appeal to Greenpeace, the UN and the governments of all countries of the world with a call to revise the negative attitude to the GMP. The appeal says that science does not know any confirmed case of the negative impact of transgenic products on human and/or animal health. International regulators recognize such products as safe, however, Greenpeace and other opponents of GM food refuse to recognize the results of fundamental and applied agronomic research [4; $13 ; 23]$. As already noted, as of 2018 , agrobiotechnology is allowed in 28 countries of the world. At the same time, another block of countries is pursuing a diametrically opposed policy aimed at reducing and sometimes a complete prohibition of the GMPs production and trade. This block includes more than 160 countries, including some CIS and EU countries.

In the EU, agricultural products produced on the basis of biotechnology are positively treated by those countries in which GM crops are allowed (GM crops account for only $0.14 \%$ of arable land in Europe [9, 28]). At the same time, Greece, Italy and a number of Balkan countries are ardent opponents. It should be noted that the EU policy on GMP, in particular, its commercialization, provision and registration of new varieties, looks rather restrained. During the first two decades of the XXI century, the categorical rejection of GMP by supporters of environmental parties, including Greenpeace, whose activists destroyed the GM crops, restrained, in some sense, the rapid spread of GM food in the EU, causing a low level of orientation of innovative strategies on GM food for the development of international agribusiness. In addition, the increased attention of society to a healthy lifestyle, including food, increasingly provides transformation of innovative development of international agribusiness in the direction of organic food portfolio and ECO-development (and not genetically modified) $[8 ; 13 ; 19]$.

However, in July of 2017, the EU member states allowed the cultivation and sale of another GM maize variety, which indirectly says that Europeans do not give up innovative solutions in the field of high technology, but carefully inspect new types of food through the prism of traceability, safety and economic feasibility.

The development, impact, implementation and commercialization issues are also discussed within the framework of the OECD, in particular at the level of the Global Biotechnology Forum which was first held in 2010 [28]. However, the GMPs are completely prohibited only in 9 countries: Russia, Poland, Egypt, Madagascar, Greece, Austria, Venezuela, Peru and Ecuador. Other countries have either imposed a moratorium or allowed only certain varieties of GM crops.

Despite the ambiguous attitude towards GMP, agrobiotechnology continues to develop and is 
reflected in innovative strategies for international agribusiness development. The recent advances in biotechnology in international agribusiness should include the commercialization of GM animals and fish, the beginning of sales of GM apples in the domestic markets of the USA and Canada (CRISPR-Cas9 technology patent), which get rid of attractive appearance (they darken) with full and/or partial loss of its integrity (a cut or a dent).

In November 2015, the US Department of Agriculture (USDA) approved the commercial use of GM animals and fish [29]. Thus, the fast-gaining GM salmon (developed by Aqua Bounty Technologies has already been available for sale since 2018). This development will reduce the production cycle by half as fish gain weight of twice the traditional method of fattening. In May 2016, GM animals and fish were also allowed in Canada and according to 2017 data, about 4.5 million tons of such fish have already been sold in the period from May 2016 to August 2017, [16; 25; 28-29].

In the same year, the US Department of Agriculture approved a new variety of GM apples, the first harvest of which was collected in autumn 2016. Okanagan Specialty Fruits is engaged in their production, and they will be marketed under the Arctic Apples trademark. Pre-sliced apples will be sold in bags so that the buyer could conveniently consume them on the road. The company plans to sell a number of varieties of apples under the Arctic Apples brand including such varieties like Golden Delicious, Granny Smith and Fuji in the future [34; 9].

The method of CRISPR-Cas9 genome correction has become the revolutionary development of the agrobiotechnology market over the last 20 years. In 2013, two independent researchers, biologists E. Charpentier at Max Planck Institute (MPI) for Biophysical Chemistry (Sweden) and J. Doudna at the University of California (USA) discovered a new method of DNA correction, which was called CRISPR-Cas9. The main advantage of this method is that the correction of DNA molecules can occur with much higher accuracy and speed through the use of anti-virus protection of bacterial cells. However, the legal disputes that arose on the issues of obtaining a patent for the CRISPR-Cas9 technology were resolved only in February 2017, as a result of which the right to preserve all patents included in this technology is reserved by the Broad Institute which is part of the Massachusetts Institute of Technology (USA). It should be noted that in September 2016, Monsanto, which is currently owned by the German giant Bayer, acquired a worldwide non-exclusive license at the Broad
Institute and Harvard University to use the CRISPR-Cas 9 technology for genome correction, with which the company plans to produce agricultural products, in particular, this technology will allow the company to significantly improve the necessary properties or remove the unwanted properties of plants, creating their more effective hybrids and varieties.

In fact, this means that the CRISPR-Cas9 technology introduces artificial manipulations with the gene beyond the limits of genetic modifications, namely food, and respectively, beyond the GMO regulatory framework. For example, in 2015, The Swedish Agriculture Council decided that plants whose gene is modified using CRISPR technology do not fall under the definition of GM food in the EU [23]. In April 2016, The US Department of Agriculture determined that new varieties of mushrooms and maize that were genetically modified using CRISPR-Cas9 technology are not GM food and do not require appropriate registration [29].

Currently, research is being carried out using the latest technology. Thus, in February 2017, the North-Western University of Agriculture and Forestry in Xianyang (China) using the CRISPRCas9 method of modifying the genome, succeeded in developing a special breed of cows. These animals were characterized by increased resistance to tuberculosis [3;9].

The role of information and communication technologies in international agribusiness has significantly increased in the last few years. This was facilitated by the spread of mobile and broadband communications and the development of the Internet. In developing countries, among $20 \%$ of the poorest population, $70 \%$ have mobile phones and more than $40 \%$ of the world's population has access to the Internet $[9 ; 25 ; 28-$ 29].

Contemporary large-scale agribusiness is practically impossible without the use of Precision Agriculture tools such as the Global Positioning System, satellites, unmanned aerial vehicle tracking, operational and reliable meteorological data. Due to their development, such complex agrotechnical operations as sowing, tillage, fertilization, crop processing operations by protection agents, taking into account the soil and landscape peculiarities, can be carried out.

Digital technologies play a pivotal role in achieving the United Nations Global Sustainable Development Goals by 2030, mainly by allowing more people and agribusiness to participate in the market, increasing the productivity of existing agricultural production methods and maintaining 
economy on the acceptable level through the creation of new business solutions, based on innovations.

A large number of smart solutions for agribusiness are available on the international and Ukrainian markets today. Thus, farmers can install special sensors in the fields that will allow them to engage in "precision farming", and to determine weather conditions, moisture content, fertilizer concentration in the soil and a number of other indicators in real time that are essential for the agribusiness efficiency. On the basis of the data obtained, farmers can quickly decide which fields and when should be fertilized, as well as take measures in accordance with natural and climatic conditions and plan the harvest in advance. In addition, they can quickly control the process of agricultural works and monitor the seeds and fertilizers consumption. At the same time, managers using the control panel which displays information about the machinery operation can prevent the misuse of fuel and agrochemicals. But the main advantage of this solution is the ability to observe the field from a bird's-eye view and to assess the condition of each agricultural site in real time. All data are available on mobile devices, which allows farmers to quickly receive information from agrosensors, and this reduces the misuse of equipment by $30 \%$ and saves up to $1 / 3$ of the stocks of seeds, chemicals and fuel.

The German enterprise-producer of SAP software is among the manufacturers of smart systems for international agribusiness. The company's business solutions provide an opportunity to track the location and condition of cattle, as well as to determine the optimal areas for their grazing through sensors installed in the animal's body and quadrocopters [19]. This approach helps international agribusiness to constantly monitor the number and health of animals, as well as the actual level of progress in the field works to respond promptly to crisis factors until they become fatal. That is, modern innovative solutions of this company are aimed at reducing costs, both in crop production and livestock.

A promising direction of development of digital technologies in international agribusiness is the establishment of the Institute of Internet of Things, whose important achievement was the introduction of unmanned agricultural machinery in agricultural production. Improvement of traditional agricultural technology offered by the SAP company, according to which agrosensors are installed in the cabin of agricultural machinery, allows the tractor to simultaneously plow the land and gather information about the soil condition and automatically send it to the agricultural database. After processing the data obtained, farmers select the relevant fertilizers for each individual agricultural site. Accordingly, on the one hand, the proposed solution reduces transaction costs, and on the other, requires the farmer's computer skills and methodology of data processing.

Currently, a new agribusiness segment has been formed on the international agro-food market, which is based on nanotechnology, which provides for the use of innovations to overcome the cell barrier, the size of which is within 1 to 100 nanometers $[4 ; 13 ; 22]$. Developments in the field of nanotechnology can be used in a large number of areas for the innovative development of international agribusiness. The use of nano-preparations in crop production as microfertilizers can increase resistance to adverse conditions and at the same time ensure an increase in the yield of food crops (potatoes, cereals, vegetables, fruits and berries) and industrial crops (cotton, flax, etc.).

M. V. Prysiazhniuk, N. V.Zubets, P. T. Sabluk, etc. [1] distinguish the following segments of the use of nanotechnology in agribusiness: 1 ) food with predetermined consumer properties; 2 ) modified basic food that retains stable taste; 3 ) food that changes color after the expiration date; 4) agricultural products for targeted supply of vitamins; 5) creation of new types of nano-fertilizers.

In the XXI century, convergent technologies started to indirectly affect the international agricultural market. Thus, the convergence of scientific knowledge in the humanities and natural sciences takes place, involving the transformation of approaches to studying the object, leveling the sectoral differences between the scientific spheres, and generating global innovation technologies.

The "converging technologies" term appeared relatively recently - in the middle of $1990 \mathrm{~s}$. This term is associated with the name of the sociologisturbanist M. Castells. The scientist observed the "convergence of specific technologies in the highly integrated system, where the outdated technologically isolated innovative trajectories acquire obscure features" $[13 ; 16]$.

This category acquired some clarity after its publication in June 2002. The US National Science Foundation prepared a report in which the author team led by M. Roco and W. Bainbridge identified the most likely areas for the STP development, which involves the merger of various technologies (nano, bio, information and communication technologies and cognitive sciences) in order to improve the life quality parameters. Scientists have determined that there is a clear tendency towards 
convergence, as abbreviations of the above technologies, that is, the NBIC technologies [20].

Various fields of activity, which previously seemed distant and divided, with the introduction of nanotechnology began to unexpectedly overlap, affect each other and show synergy, that is, a clear tendency to merge with biological and information technologies and approaches, which has already led to the creation of a serious scientific concept on the convergence of a number of scientific disciplines [22].

The convergence of nano-, bio- and information and communication technologies in international agribusiness contributes to the growth of agricultural production efficiency. Thus, the nanosensors monitor the health and feeding of the cattle, informing the farmer through the personal computer of the problems that arise, and also suggest possible solutions.

S. Bonny [23] refers to a number of characteristics to the specifics of the impact of NBIC technologies in the international agro-food market, among which the leading place is occupied by 1 ) the fundamental nature of technologies (first, an idea emerges that moves through the innovation cascade, and turns into food); 2) the interdisciplinary nature of food production; 3 ) each of the technologies identified in the abbreviation forms an instrumental basis for the development of other related technologies; 4 ) a wide coverage of fundamental agro-industries; 5) the synergetic effect.

Research in the field of bio-and nanotechnology is a promising area of development of NBIC technologies in international agribusiness. Thus, according to M. Roco and W. Bainbridge, they allow creating applied tools for cultivating crops, improving the efficiency of introduction and further use of various types of fertilizers and pesticides. Using bio-, nano-sensors, the grocery segment of the international agribusiness can obtain relevant information about the degree of freshness of agricultural products, instead of discarding it after the expiration date indicated on the package.

Nanobiotechnology research is experimental in nature and is currently not competitive compared with traditional chemicals. Such research is carried out in universities and laboratories not only in developed countries but also in developing countries. For example, within the framework of the cooperation program, the scientific laboratories of Mexico and India are working on the development of non-toxic nanoherbicide, which in the long run substantially transforms the added value agro-food chains reducing them to three segments: "land — carbon dioxide - milk" [23].

\section{CONCLUSIONS FROM THIS STUDY AND PROSPECTS FOR FURTHER EXPLORATION IN THIS DIRECTION}

Agro-economics has no single theoretical, methodological and methodological approaches to measuring structural and dynamic changes in international agribusiness through the processes of global distribution of agronomy innovations, and therefore there is no full clarity in the study of the laws of its development and the remote consequences of the transformational processes taking place under the influence of innovations. A real result of the transformational progress in international agribusiness is the system of quantitative and qualitative indicators, the key among which is GDP. Analysis of statistical data showed that the share of international agribusiness in world GDP is constantly decreasing and this trend is determining for almost all developing countries. This leads to the rejection in national development models from the theory of comprehensive extensible economic growth and the transition to the concept of innovation-oriented sustainable development. Consequently, the innovative aspects of the international agribusiness development today are experiencing an accelerating increase in their critical mass. They will determine the new leaders of the international food market in the medium term. In recent years, the volume of innovations in startups specializing in new agricultural technologies has increased more than tenfold. Big data, robotics, artificial intelligence and other technologies are becoming common not only on the industrial conveyor but also in agricultural production. The process of change is not just about startups. It is expected that mergers and acquisitions of agrotechnological companies will continue in the Big six. Another important trend is the active development of centers for the development and implementation of advanced agrotechnologies as an innovative instrument of state support for agribusiness development.

In addition, despite the fact that the share of agribusiness in world GDP has been steadily decreasing, research and development costs, on the contrary, are increasing at a quick pace every year. Moreover, the planned trend to reduce the share of state financing of these costs is completely brought to naught by private investment from the corporate sector of international agribusiness. That is, the availability of powerful financial resources and internationalization of activities allows the agro-oriented transnational enterprise 
conducting their own research policy in the field of bio-, nano- and information and communication technologies that are the most capital intensive.

Consequently, the changes taking place in the international agro-food market during the "green" and "gene" revolution, have created the prerequisites for the formation of high-tech agricultural sectors in the world of innovation-oriented agrofood model of the XXI century. Today, agribusiness, being the most conservative sector of the economy, continues to acquire the features of a knowledge-intensive and high-tech sector at a rapid pace, and this applies to both large agricultural companies (agricultural holdings) and small farmers, including private farms.

In the conditions of innovation and tecnification of the world food market, further, conditionally sustainable development of Ukrainian agribusiness is possible without active involvement in the process of implementation and effective use of high-tech methods of agricultural production. Despite the fact that the foreign policy situation associated with obtaining trade preferences in the food markets of the EU member states and the USA and the domestic situation, which considerably complicated domestic logistics, limited access to financial capital markets, at the same time allowed to form new sources of sustainable economic growth within the Ukrainian agricultural economy. Thus, the most promising hightech technologies in the introduction of electronic agricultural production (e-agriculture) is a network farm, smart agricultural machines and the Internet of Things in terms of food circulation or meeting the needs of agribusiness in sowing material, plant and animal protection products. This will ensure the formation of stable network connections between all participants of the agrofood chain, more equitable pricing, elimination of information asymmetry between the participants of the food market, rationalization of the use of natural resources, monitoring of the quality and traceability of agricultural products.

The effectiveness of the implementation of the selected areas depends on the strategic constants of agribusiness development chosen by the state for the future. The formation of new innovative approaches is closely related to the transformation of the structural and functional nature of Ukrainian agribusiness, changes in the institutional environment and the organizational and economic mechanism of its functioning.

\section{Мітература:}

1. Аграрний сектор економіки України (стан і перспективи розвитку) / [Присяжнюк М.B.,
Зубець М.В., Саблук П.Т. та ін.]; за ред. М.В. Присяжнюка, М.В. Зубця, П.Т. Саблука, В.Я. Месель-Веселяка, М.М. Федорова. - К.: ННЦ "IAE", 2011. - 1008 c.

2. Белл А., Иноземцев В.А. Эпоха разобщенности: Размышления о мире XXI века. - M.: Центр исследований постиндустриального общества, 2007. - 304 с.

3. Випереджаючий інноваційний розвиток: теорія, методика, практика: монографія / За ред. к.е.н., доцента Ілляшенко Н.С. - Суми: Триторія, 2018. - 484 с.

4. Гасанов С. Синопсис мирового опыта построения системы обеспечения продовольственной безопасности / С. Гасанов, С. Петруха, Н. Петруха // Економіст. - 2014. - № 10. - C. 25-30.

5. Зубець М. В. Інноваційно-випереджувальна модель якісно нового розвитку агропромислового виробництва / М.В. Зубець, П.Т. Саблук, С.О. Тивончук // Економіка АПК. - 2008. № $12 .-$ C. $3-8$.

6. Інноваційно-інформаційна економіка: зміст, динаміка, регулювання / [Тарасевич В.M. та ін.; за ред. В.С. Тарасевич]. - Аніпро: Економіка, 2018. - 351 с.

7. Макаренко П.М. Концептуальні засади системного інноваційного оновлення сільськогосподарського виробництва / П.М. Макаренко, Н.К. Васильєва // Агросвіт. - 2008. — № 1. - C. 17-26.

8. Международный форум технологического развития. Инфографика о технологических укладах. [Електронный ресурс]. - Режим доступу: http://forumtechnoprom.com/page/121

9. Національне бюро економічних досліджень CШA (NBER) [Електронний ресурс]. Режим доступу: https://nber.org

10. Петруха С.В. Ринкова трансформація аграрного сектору економіки України: від аграрної кризи до формування підвалин реалізації глобальних цілей сталого розвитку / С.В. Петруха // Агросвіт. - 2017. - № 18. C. 3-46.

11. Петруха С.Ао питання природи та ідентифікації структурних зрушень в економіці: методологічний аспект / С. Петруха, Н. Петруха // Економіст. - 2013. - № 8. - С. 23-26.

12. Петруха С.В. Передумови та перспективи технологічної модернізації аграрного сектору економіки України / Проблеми та перспективи фінансового забезпечення аграрного сектору: вітчизняний та зарубіжний досвід // матеріали Міжнародної науково-практичної конференції (м. Київ, 13-14 вересня 2018 року) Київ: ЦП "КОМПРИНТ", 2018. - С. 173-176. 
13. Положение дел в связи с отсутствием продовольственной безопасности в мире 2015. На пути к достижению намеченных на 2015 г. международных целей в области борьбы с голодом: обзор неравномерных результатов / Продовольственная и сельскохозяйственная организация Объединенных Наций. - Рим: ФАО, 2015. - 72 c.

14. Пономарьов О. С. Інституціональні складові управління інноваційно-інвестиційним розвитком суб'єктів аграрного бізнесу / О.С. Пономарьов // Вісник Харківського національного технічного університету сільського господарства імені Петра Василенка. - 2018. Вип. 191. - С. 297-311.

15. Рижикова Н.І. Управління інноваційноінвестиційною діяльністю підприємств та об'єднань агропромислового виробництва: стратегії, механізми та інструментарій: [монографія] / Н.І. Рижикова. - Харків: Вид-во "Смугаста типографія", 2017. - 321 с.

16. Світовий центр даних з геоінформатики та сталого розвитку [Електронний ресурс]. Режим доступу: http://wdc.org.ua/uk

17. Соснін О.В. Сучасні міжнародні системи та глобальний розвиток (соціально-політичні, соціально-економічні, соціально-антропологічні виміри) / О.В. Соснін, В.Г. Воронкова, О.Є. Постол. - К.: Центр навч. л-ри, 2015. $-554 \mathrm{c}$.

18. Управління інноваційно-технологічним розвитком агросфери: монографія / М.Г. Аобас, В.В. Россоха, А.О. Соколов; за ред. М.Г. Мобаса. - К.: ННЦ "IAE", 2016. - 416 с.

19. Acemoglu D. Innovation, Relocation and Growth / D. Acemoglu, U. Akcigit, N. Bloom, W. Kerr. - 2013. Mode of access: https:// www.nber.org/papers/w18993

20. Agricultural investment funds for developing countries / Food and Agriculture Organization of the United Nations. Rome. - 2010. Mode of access: http://www.fao.org/fileadmin/user_upload/ags/publications/investment_funds.pdf

21. An Economic History of Europe. From Expansion to Development / Edited by A.D. Vittorio. Routledge. - 2006. Mode of access: https:/ /zodml.org/sites/default/files/\%5BAntonio_Di_Vittorio\%5D_An_Economic_History_of_Europ_0.pdf

22. Anderson K. Globalization's Effects on World Agricultural Trade, 1960-2050 / K. Anderson// Philosophical Transactions of The Royal Society (Biological Science). - Vol. 365. - 2010. - P. 3008-3009.

23. Bonny S. Corporate Concentration and Technological Change in the Global Seed Industry
/ S. Bonny // Sustainability. - Paris. - INRA. 2017. Vol. 9. - № 9. - 25 p.

24. Bornhost F., Commander S. Multiplicative effect of government investment in science and infrastructure projects / F. Bornhost, S. Commander // Economics of Transition. - № 14 (2). - 2006. - P. 269-288.

25. FAO. FAOSTAT. Mode of access: http:// www.fao.org/faostat/en/\#home.

26. Food security indicators: Statistics / Food and Agriculture Organization of the United Nation. Mode of access: http://www.fao.org/ economic/ess/ess-fs/ess-fadata/ru/\#.XNRLLY77TcA

27. Mensch G. Das Technologische Patt: Innovationen uberwinden die depression. Frafurt am Main: Umschau Verlag, 1975. — 115 p.

28. OECD Agriculture Statistics/ OECD iLibrary. Mode of access: https://data.oecd.org/ agriculture.htm

29. USAID. Idea. Mode of access: https:// idea.usaid.gov

\section{References:}

1. Prysiazhniuk, M.V. Zubets', M.V. and Sabluk, P.T. (2011), Ahrarnyj sektor ekonomiky Ukrainy (stan i perspektyvy rozvytku) [Agrarian sector of Ukraine's economy (state and prospects of development)], NNTs "IAE", Kyiv, Ukraine.

2. Bell, D. and Ynozemtsev, V.L. (2007), Epokha razobschennosty: Razmyshlenyia o myre XXI veka [The Age of Disunity: Reflections on the World of the XXI Century], Tsentr yssledovanyj postyndustryal'noho obschestva, Moscow, Russia.

3. Illiashenko, N.S. (2018), Vyperedzhaiuchyj innovatsijnyj rozvytok: teoriia, metodyka, praktyka [Outstanding innovative development: theory, methodology, practice], Trytoriia, Sumy, Ukraine.

4. Hasanov, S. Petrukha, S. and Petrukha, N. (2014), "Synopsis of world experience in building a system to ensure food security", Ekonomist, vol. 10 , pp. $25-30$.

5. Zubets', M.V. Sabluk, P.T. and Tyvonchuk, S.O. (2008), "Innovative and forward-looking model of qualitatively new development of agroindustrial production", Ekonomika APK, vol. 12, pp. 3-8.

6. Tarasevych, V.M. (2018), Innovatsijnoinformatsijna ekonomika: zmist, dynamika, rehuliuvannia [Innovation-informational economy: content, dynamics, regulation], Ekonomika, Dnipro, Ukraine.

7. Makarenko, P.M. and Vasyl'ieva, N.K. (2008), "Conceptual framework of system 
innovation innovation of agricultural production", Ahrosvit, vol. 1, pp. 17-26.

8. International Forum of Technological Development (2013), "International Forum for Technological Development. Technology infographics", available at: http://forumtechnoprom.com/page/121 (Accessed 30 May 2019).

9. National Bureau of Economic Research (2019), available at: https://nber.org (Accessed 30 May 2019).

10. Petrukha, S. V. (2017), "Market transformation of agricultural sector of Ukraine's economy: from agricultural crisis to formation the basis for achievement the global sustainable development goals", Ahrosvit, vol. 1, pp. 3-46.

11. Petrukha, S. and Petrukha, N. (2013), "To the question of nature and identification of structural changes in the economy: the methodological aspect", Ekonomist, vol. 8, pp. 23-26.

12. Petrukha, S.V. (2018), "Preconditions and prospects of technological modernization of the agrarian sector of the Ukrainian economy", Problemy ta perspektyvy finansovoho zabezpechennia ahrarnoho sektoru: vitchyznianyj ta zarubizhnyj dosvid. Materialy Mizhnarodnoi naukovo-praktychnoi konferentsii [Problems and prospects of financial provision of the agrarian sector: domestic and foreign experience. Materials of the International Scientific and Practical Conference], Kyiv, Ukraine, KOMPRYNT, 13-14 Sept, pp. 173-176.

13. FAO (2015), Polozhenye del v sviazy s otsutstvyem prodovol'stvennoj bezopasnosty $\mathrm{v}$ myre - 2015. Na puty k dostyzhenyiu namechennykh na $2015 \mathrm{~h}$. mezhdunarodnykh tselej v oblasty bor'by s holodom: obzor neravnomernykh rezul'tatov [The State of Food Insecurity in the World - 2015. Towards Achieving the 2015 International Goals to End Hunger Objectives: A Review of Uneven Results], FAO, Rome, Italy.

14. Ponomar'ov, O.S. (2018), "Institutional components of management of innovation and investment development of subjects of agrarian business", Visnyk Kharkivs'koho natsional'noho tekhnichnoho universytetu sil's'koho hospodarstva imeni Petra Vasylenka, vol. 191, pp. 297-311.

15. Ryzhykova, N.I. (2017), Upravlinnia innovatsijno-investytsijnoiu diial'nistiu pidpryiemstv ta ob'iednan' ahropromyslovoho vyrobnytstva: stratehii, mekhanizmy ta instrumentarij [Management of innovation and investment activities of enterprises and associations of agro-industrial production: strategies, mechanisms and tools], Vyd-vo "Smuhasta typohrafiia", Kharkiv, Ukraine.

16. World Data Center for Geoinformatics and Sustainable Development (2019), available at: http://wdc.org.ua/uk (Accessed 30 May 2019).

17. Sosnin, O.V. Voronkova, V.H. Postol, O.Ye. (2015), Suchasni mizhnarodni systemy ta hlobal'nyj rozvytok (sotsial'no-politychni, sotsial'no-ekonomichni, sotsial'no-antropolohichni vymiry) [Modern international systems and global development (socio-political, socio-economic, social and anthropological dimensions)], Tsentr navch. literatury, Kyiv, Ukraine.

18. Lobas, M.H. Rossokha, V.V. and Sokolov, D.O. (2016), Upravlinnia innovatsijno-tekhnolohichnym rozvytkom ahrosfery [Management of innovation and technological development of the agrosphere], NNTs "IAE", Kyiv, Ukraine.

19. Acemoglu, D. Akcigit, U. Bloom, N. and Kerr, W. (2013), "Innovation, Relocation and Growth", available at: https://www.nber.org/papers/w18993 (Accessed 30 May 2019).

20. FAO (2010), "Agricultural investment funds for developing countries", available at: http://www.fao.org/fileadmin/user_upload/ags/publications/ investment_funds.pdf (Accessed 30 May 2019).

21. Vittorio, A. D. (2006), "An Economic History of Europe. From Expansion to Development", available at: https://zodml.org/sites/ default/files/\%5BAntonio_Di_Vittorio\%5D_An_Economic_History_of_Europ_0.pdf (Ācessed 30 May 2019).

22. Anderson, K. (2010), "Globalization's Effects on World Agricultural Trade, 1960-2050", Philosophical Transactions of The Royal Society (Biological Science), vol. 365, pp. 3008-3009.

23. Bonny, S. (2017), "Corporate Concentration and Technological Change in the Global Seed Industry", Sustainability, vol. 9, no. 9.

24. Bornhost, F. and Commander, S. (2006), "Multiplicative effect of government investment in science and infrastructure projects", Economics of Transition, vol. 14 (2), pp. 269-288.

25. FAO (2019), "FAOSTAT", available at: http://www.fao.org/faostat/en/\#home (Accessed 30 May 2019).

26. FAO (2018), "Food security indicators : Statistics", available at: http://www.fao.org/economic/ess/ess-fs/ess-fadata/ru/\#.XNRLLY77TcA (Accessed 30 May 2019).

27. Mensch, G. (1975), Das Technologische Patt: Innovationen uberwinden die depression, Umschau Verlag, FRG.

28. OECD iLibrary (2019), "OECD Agriculture Statistics", available at: https://data.oecd.org/ agriculture.htm (Accessed 30 May 2019).

29. USAID (2019), "Idea", available at: https:/ /idea.usaid.gov (Accessed 30 May 2019).

Стаття надійшла до редакиії 11.06.2019 p. 